\section{Regulation of Root Distribution and Depth by Phosphorus Localization in Agrostis stolonifera}

\author{
Eric M. Lyons ${ }^{1,4}$ \\ Department of Crop and Soil Sciences, 116 ASI Building, The Pennsylvania \\ State University, University Park, PA 16802
}

Robert H. Snyder ${ }^{2}$ and Jonathan P. Lynch
Department of Horticulture, 221 Tyson Building, The Pennsylvania State
University, University Park, PA 16802

Additional index words. creeping bentgrass, alumina-buffered phosphorus, plant nutrition, turfgrass

\begin{abstract}
Root distribution in turfgrass systems influences drought tolerance and resource competition with undesirable species. We hypothesized that spatial localization of phosphorus (P) supply would permit manipulation of turfgrass root distribution. To test this hypothesis, creeping bentgrass (Agrostis stolonifera L.) plants were exposed to localized $P$ supply in two experiments. The first experiment split the root zone horizontally into two different growth tubes and the second used alumina-buffered $P$ (Al-P) to localize $P$ availability deeper within a continuous root zone. In the horizontally split root zones, heterogeneous $P$ availability led to no difference in shoot growth compared with uniform $P$ availability. Root proliferation was greatest in the growth tube with available $P$ compared with the growth tube without $P$. The use of Al-P, regardless of its spatial distribution, doubled root-to-shoot ratios compared with soluble $P$. Much of the increase in the ratio was accounted for by reduced shoot growth. Use of Al-P increased rooting deeper in the root zone, especially when the Al-P was mixed only in the lower portion of the root zone. Our results are consistent with the hypothesis that root distribution of creeping bentgrass can be manipulated by spatial localization of $P$ supply in the root zone and indicate that relative biomass allocation to roots and shoots may be manipulated with buffered $P$ sources.
\end{abstract}

Healthy root systems are essential to maintain turfgrass quality in the demanding environment of golf greens. Increased rooting of creeping bentgrass on golf greens can increase drought tolerance (DaCosta and Huang, 2006), nitrogen uptake (Bowman et al., 1998), and the general health of the turfgrass. When rooting is limited, like in compacted soils, more shallowly rooted species such as annual bluegrass (Poa annua L.) can become invasive (Klecka, 1937). Deeper-rooted creeping bentgrass would also reduce the need for supplemental irrigation because the plant would be able to extract water from deeper in the root zone. The ability to regulate root distribution in turfgrass systems would therefore be an important tool for turfgrass managers.

Phosphorus (P) availability regulates a variety of plant characteristics, including

\footnotetext{
Received for publication 12 Mar. 2008. Accepted for publication 8 Aug. 2008.

${ }^{1}$ Graduate Research Assistant. Current position: Assistant Professor. Current address: Department of Plant Agriculture, E. C. Bovey Building, University of Guelph, Guelph, Ontario, N1G 2W1, Canada.

${ }^{2}$ Research Associate.

${ }^{3}$ Professor

${ }^{4}$ To whom reprint requests should be addressed; e-mail elyons@uoguelph.ca
}

consisting of phosphate adsorbed to small particles of aluminum oxide (Al-P) and can be mixed into sand culture to maintain $\mathrm{P}$ levels at low concentrations ( $\mu \mathrm{mol}$ levels) over an extended period of time (Coltman et al., 1982; Elliott, 1989; Lynch et al., 1990). The solid alumina releases micromolar concentrations of $\mathrm{P}$, acting as a buffer, using equilibrium exchange between solution phosphate and solid phase-adsorbed phosphate. In this way, it mimics the $\mathrm{P}$ buffering that occurs in soil through complex chemical and biological mechanisms (Comerford, 1998) and the alumina can be used to provide optimal $\mathrm{P}$ nutrition over time. This is in contrast to slow-release fertilizers, which can maintain adequate $\mathrm{P}$ concentrations in the root zone over extended periods of time but release $\mathrm{P}$ as a function of pellet dissolution rather than plant requirements and do not prevent $\mathrm{P}$ leaching in sandy soils (Havis and Baker, 1985).

Research with soilless media indicates that addition of Al-P at $1 \%$ of the volume of the dry medium is sufficient for optimal plant performance of floriculture crops and for vegetable production in the field (Brown et al., 1999; Lin et al., 1996; Tanaka et al., 2006). Preliminary work with turf species demonstrated that creeping bentgrass grew satisfactorily in $80 \%$ sand: $20 \%$ peat with $1 \%$ Al-P as the sole source of P (Lyons et al., 2000). Because soluble $P$ concentrations remain very low with buffered $\mathrm{P}$ sources, negligible amounts of $\mathrm{P}$ are lost even if large quantities of water flow through the medium. In the systems that have been tested, leaching has been reduced to less than $1 \%$ of that in conventionally fertilized systems (Borch et al., 1998; Lin et al., 1996).

The placement of $\mathrm{P}$ deeper in the root zone may permit deeper rooting, thereby improving heat tolerance, recuperative ability, drought resistance, and overall turfgrass health. The objective of these experiments was to determine whether creeping bentgrass roots responded to spatial $\mathrm{P}$ supply and to determine whether deeper rooting could be encouraged by placing Al-P deeper in a sandbased root zone.

\section{Materials and Methods}

Plant material. All experiments used 'Pennlu', a vegetatively propagated cultivar of creeping bentgrass (Anonymous, 1954). Initially, mature tillers were transplanted (one each) into Conetainers (Stuewe and Sons Inc., Corvallis, OR), $2.5 \mathrm{~cm}$ in diameter and $15 \mathrm{~cm}$ deep, filled with silica sand conforming to USGA specifications (Green Section Staff, 1993) to allow for root growth and ease of washing when they were later transplanted into the split root apparatus for the horizontal split root experiment. The same source of sand was used for both experiments. The experiment was initiated before the tillers began to vegetatively reproduce. Tillers from the original stand, maintained in the greenhouse, were used in the vertical $\mathrm{P}$ localization experiment. 
Horizontal split root. The experiment was conducted in Summer 2000 in a climatecontrolled greenhouse at 18 to $22{ }^{\circ} \mathrm{C}$ with a minimum daily photoperiod of $12 \mathrm{~h}$ (lat. $40.79^{\circ} \mathrm{N}$, long. $77.86^{\circ} \mathrm{W}$ ). The experiment used an apparatus that allowed the roots to be separated horizontally into two different 2.5$\mathrm{cm}$ diameter Conetainers filled with sand. The separation was accomplished by using $1.25-\mathrm{cm}$ polyvinyl chloride (PVC) plumbing junctions. Tillers were removed from the Conetainers, the sand was washed from the roots, and the existing root mass was separated so that approximately equal amounts of roots were placed through a $\mathrm{T}$ junction and an elbow joint on each side directing the roots into a Conetainer (Fig. 1A). After transplanting the plants, the PVC T junction was filled with silica sand to hold moisture and to protect the top portion of the roots from desiccation.

Immediately after transferring the plants, nutrient treatments were randomly applied to the root growth tubes on each side of the apparatus. Three treatments were applied: plants received nutrient solution containing $\mathrm{P}$ 1) in both sides of the root zone (HH); 2) with no $\mathrm{P}$ on either sides of the root zone (LL); or 3) with $\mathrm{P}$ on one side and nutrient solution without $\mathrm{P}$ on the other (HL). Nutrient solutions were added twice weekly and the plants were watered daily or as needed. The nutrient solutions were a complete nutrient solution providing $4.4 \mathrm{mmol} \cdot \mathrm{L}^{-1}$ nitrogen (3.88 mmol. $\mathrm{L}^{-1} \mathrm{NO}_{3}, 0.50 \mathrm{mmol} \cdot \mathrm{L}^{-1} \mathrm{NH}_{4}$ ), $1.5 \mathrm{mmol} \cdot \mathrm{L}^{-1}$ potassium, $0.5 \mathrm{mmol} \cdot \mathrm{L}^{-1} \mathrm{P}$, $0.94 \mathrm{mmol} \cdot \mathrm{L}^{-1}$ calcium, $0.25 \mathrm{mmol} \cdot \mathrm{L}^{-1} \mathrm{mag}-$ nesium, and $0.25 \mathrm{mmol} \cdot \mathrm{L}^{-1}$ sulfur and a phosphorus-free solution that provided 4.4 $\mathrm{mmol} \cdot \mathrm{L}^{-1}$ nitrogen $\left(3.88 \mathrm{mmol} \cdot \mathrm{L}^{-1} \mathrm{NO}_{3}, 0.50\right.$ $\left.\mathrm{mmol} \cdot \mathrm{L}^{-1} \mathrm{NH}_{4}\right), 1.5 \mathrm{mmol} \cdot \mathrm{L}^{-1}$ potassium, $1.19 \mathrm{mmol} \cdot \mathrm{L}^{-1}$ calcium, $0.25 \mathrm{mmol} \cdot \mathrm{L}^{-1} \mathrm{mag}-$ nesium, and $0.25 \mathrm{mmol} \cdot \mathrm{L}^{-1}$ sulfur. Both solutions were supplemented with a complete micronutrient solution containing $23 \mu \mathrm{mol} \cdot \mathrm{L}^{-1}$ boron, $1.85 \mu \mathrm{mol} \cdot \mathrm{L}^{-1}$ copper, $22 \mu \mathrm{mol} \cdot \mathrm{L}^{-1}$ iron, $11 \mu \mathrm{mol} \cdot \mathrm{L}^{-1}$ manganese, $1.5 \mu \mathrm{mol} \cdot \mathrm{L}^{-1}$ molybdenum, and $10 \mu \mathrm{mol} \cdot \mathrm{L}^{-1}$ zinc.

The plants were transferred on 15 June and data collected 15 Aug. The plants were harvested by clipping the roots at the end of the PVC elbows where they entered the 2.5$\mathrm{cm}$ diameter root growth tube. The shoots were clipped at the top of the PVC T joint. The root mass contained within the PVC elbows and $\mathrm{T}$ joint was not measured because it was difficult to remove completely. The roots from each growth tube were washed and both roots and plant shoots were dried at $70{ }^{\circ} \mathrm{C}$ for $48 \mathrm{~h}$. For analysis of tissue $\mathrm{P}$ concentration, subsamples of the dried samples were ground and ashed at $495{ }^{\circ} \mathrm{C}$ for $10 \mathrm{~h}$. The ash was dissolved in $4 \mathrm{~mL}$ of 100 $\mathrm{mmol} \cdot \mathrm{L}^{-1} \mathrm{HCl}$ and analyzed for $\mathrm{P}$ spectrophotometrically (Murphy and Riley, 1962).

The experiment used a completely randomized design with five replicates per treatment per harvest. Differences in root mass and $\mathrm{P}$ concentration between the two sides of the split root system were analyzed using a paired Student's $t$ test. Differences in shoot mass and shoot $\mathrm{P}$ concentration were evaluated using Fisher's protected least significant difference (LSD).

Vertical localization of phosphorus. The vertical P localization experiment was a 9 -week growth study in which plants were grown in 38-cm deep, 10-cm diameter PVC pots in an attempt to simulate a golf green root zone. The pots were filled with $8 \mathrm{~cm}$ of pea gravel and then topped with $30 \mathrm{~cm}$ of sand, both conforming to USGA specifications for golf greens (Green Section Staff, 1993). The control contained sand throughout the root zone. The other treatments included sand mixed with Al-P fertilizer buffering the soil solution at $30 \mu \mathrm{mol} \cdot \mathrm{L}^{-1} \mathrm{P}$ with two different application techniques, a homogeneous mix (1\% Al-P) and a 10-cm deep band starting $20 \mathrm{~cm}$ below the surface (1\% Al-P band) (Fig. 1B). The Al-P was mixed into the sand at a rate of $10 \mathrm{~g} \cdot \mathrm{L}^{-1}(1 \%$ weight by volume). Alumina-P granules fall within the particle size distribution of the sand used within the experiments and have not been shown to significantly alter soil physical properties or $\mathrm{pH}$ at the concentrations used in these experiments. Buffering capacity was determined by placing $1 \mathrm{~g}$ of the material in $20 \mathrm{~mL}$ of deionized water, agitating, and measuring the $\mathrm{P}$ concentration of the solution after $24 \mathrm{~h}$ (Murphy and Riley, 1962).

All pots were filled in three steps: the 10 $\mathrm{cm}$ of gravel was placed into each pot and then the first $10 \mathrm{~cm}$ of sand or sand + Al-P was filled and allowed to settle with two waterings over $24 \mathrm{~h}$ and then the remaining $20 \mathrm{~cm}$ of the root zone was filled with the appropriate material. The pots were then irrigated daily for 2 weeks to allow for settling. Pots were topped off if needed. The three treatments reported in this experiment are the control, $1 \%$ Al-P mixed, and 1\% Al-P band.

The plants were transplanted from a maintained stand of Pennlu creeping bentgrass from a greenhouse. Three to four tillers were planted in each pot on 16 and 17 Dec. 2002, and the pots were placed in a
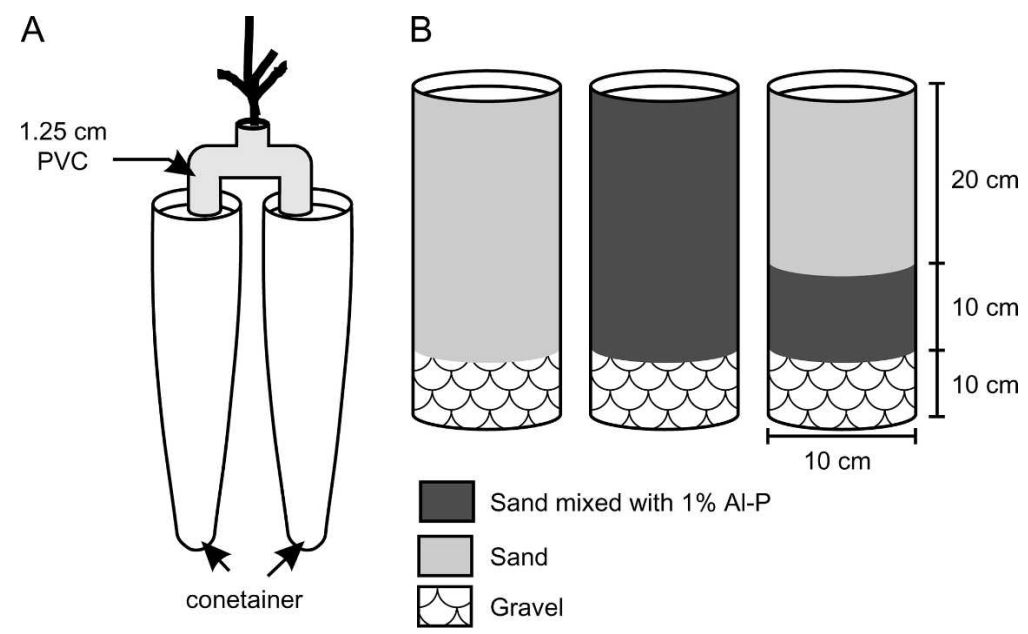

Fig. 1. (A) Horizontal split root apparatus. (B) Root zone profiles used for vertical localization of phosphorus experiment.

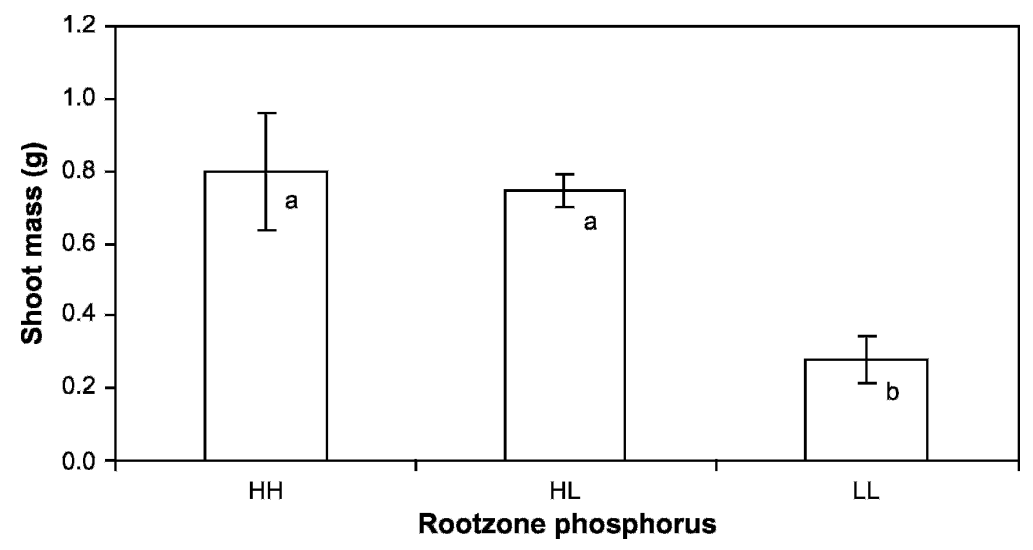

Fig. 2. Shoot mass from the horizontal split root experiment. HH received phosphorus on both sides of the root zones. HL received phosphorus on only one side of the root zone. LL received no phosphorus on either side of the root zone. Error bars represent the SE; bars within experiment labeled with the different letters are significantly different (Fisher's protected least significant difference, $P=0.05$ ). 
climate-controlled greenhouse ( 18 to $22{ }^{\circ} \mathrm{C}$ with natural light supplemented to maintain a minimum of a 12-h daylength). The plants were irrigated with tap water for 1 week and then irrigated daily with nutrient solution. The control received a complete nutrient solution providing $4.4 \mathrm{mmol} \cdot \mathrm{L}^{-1}$ nitrogen (3.88 mmol $\cdot \mathrm{L}^{-1} \mathrm{NO}_{3}, 0.50 \mathrm{mmol} \cdot \mathrm{L}^{-1} \mathrm{NH}_{4}$ ), $1.5 \mathrm{mmol} \cdot \mathrm{L}^{-1}$ potassium, $0.5 \mathrm{mmol} \cdot \mathrm{L}^{-1} \mathrm{P}$, $0.94 \mathrm{mmol} \cdot \mathrm{L}^{-1}$ calcium, $0.25 \mathrm{mmol} \cdot \mathrm{L}^{-1} \mathrm{mag}-$ nesium, and $0.25 \mathrm{mmol} \cdot \mathrm{L}^{-1}$ sulfur and the Al-Pamended treatments received a nutrient solution without $\mathrm{P}$ providing $4.4 \mathrm{mmol} \cdot \mathrm{L}^{-1}$ nitrogen (3.88 mmol. $\cdot \mathrm{L}^{-1} \mathrm{NO}_{3}, 0.50 \mathrm{mmol} \cdot \mathrm{L}^{-1} \mathrm{NH}_{4}$ ), $1.5 \mathrm{mmol} \cdot \mathrm{L}^{-1}$ potassium, $1.19 \mathrm{mmol} \cdot \mathrm{L}^{-1} \mathrm{cal}-$ cium, $0.25 \mathrm{mmol} \cdot \mathrm{L}^{-1}$ magnesium, and 0.25 $\mathrm{mmol} \cdot \mathrm{L}^{-1}$ sulfur. Both solutions were supplemented with a complete micronutrient solution described previously.

The plants were mowed to a height of $5 \mathrm{~cm}$ on $13 \mathrm{Jan}$. and the first of 10 weekly harvests was performed on 15 Jan. 2003. The plants were clipped just below the sand surface to assure that both the crown and stem tissue were included in the shoot mass. The tillers were separated and counted and the shoots were dried at $60{ }^{\circ} \mathrm{C}$ and weighed. The shoots were then ashed at $500{ }^{\circ} \mathrm{C}$ and analyzed for $\mathrm{P}$ concentration as described previously. After the seventh week, the tillers were no longer counted as a result of the large number present in each pot. The entire root zone was harvested for the first 7 weeks. In Weeks 8 to 9 , the root zone was split into the top $15 \mathrm{~cm}$ and the bottom $15 \mathrm{~cm}$. The two portions of the root zone were then washed separately. The roots were washed by hand using a sieve, were dried at $60{ }^{\circ} \mathrm{C}$, and weighed. Samples were ashed at $605{ }^{\circ} \mathrm{C}$ until the organic matter was burned off $(10 \mathrm{~h})$. The ash weight was then subtracted from the dry weight to adjust for sand in the sample resulting in an ash-free dry weight for the root samples.

The experiment used a completely random design and four replicates per treatment were harvested on each harvest date. Statistical analysis of the data was performed using JMP (SAS, Cary, NC). Difference in growth parameters and $\mathrm{P}$ concentration were analyzed by analysis of variance. When warranted, Fisher's protected LSD was used for means separation.

\section{Results and Discussion}

Horizontal split root. The plants receiving no $\mathrm{P}$ in either side of the root zone had a greater than $50 \%$ reduction in shoot growth compared with treatments receiving P (Fig. 2 ). The treatment receiving $P$ on only one side of the root zone had shoot growth that was similar to the growth of the plants receiving $\mathrm{P}$ on both sides of the root zone (Fig. 2). Root growth was reduced in the "no $\mathrm{P}$ " treatment providing evidence of $\mathrm{P}$ deficiency resulting in reduced mass of the entire plant (Fig. 3). Root mass in the side of the root zone receiving $\mathrm{P}(0.309 \mathrm{~g})$ was greater than the side receiving no $\mathrm{P}(0.188 \mathrm{~g})$.
These results show that creeping bentgrass alters its root architecture with a nonuniform supply of $\mathrm{P}$ as observed in several species (reviewed in Hodge, 2004; Robinson, 1994). The mechanism for this preferential root allocation is believed to be increased lateral branching of fine roots from parent roots in zones of enriched nitrogen or $\mathrm{P}$ availability (Huang and Eissenstat, 2000). Root proliferation is not always the response to localized nutrient supply. In some instances, increased uptake rates can confer a similar advantage to the plant and may have been selected for in crop plants because the carbon expense of increased uptake capacity is lower than root proliferation (Robinson, 2001). Despite being selected for growth in the uniform environment of golf greens (Huff and Landschoot, 1999), creeping bentgrass appears to be in the category of plants that respond to localized $\mathrm{P}$ supply with root proliferation. This is possibly because breeding of creeping bentgrass has not generally selected for increased shoot growth and maximum reproductive ability at the cost of root proliferation as with many grain crops. In addition, the breeding history of creeping bentgrass is relatively short in comparison with annual

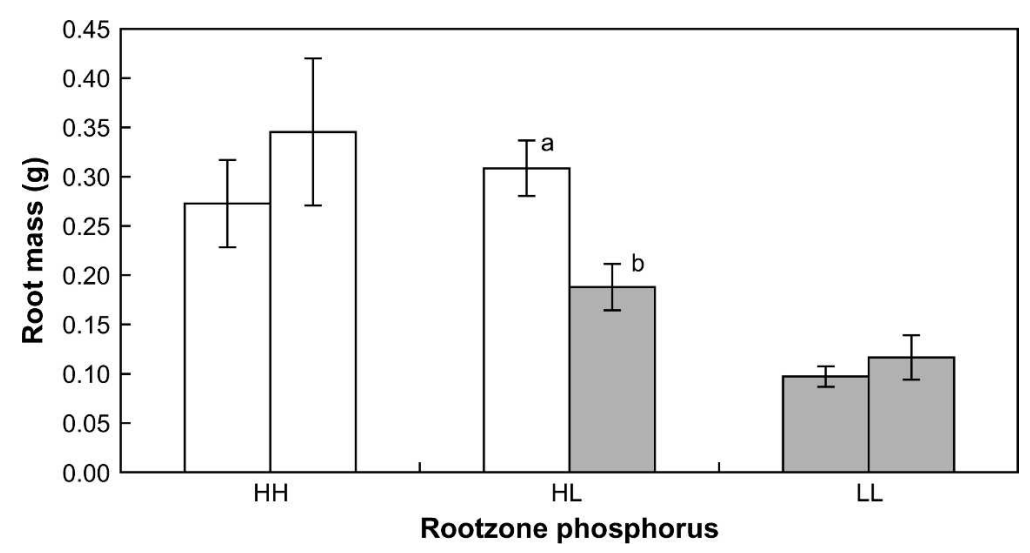

Fig. 3. Root mass from the horizontal split root experiment. HH received phosphorus on both sides of the root zones. HL received phosphorus on only one side of the root zone. LL received no phosphorus on either side of the root zone. Shaded bars represent root mass from the no phosphorus portion of the root zone and white bars represent root mass from the side with phosphorus added. Error bars represent SE; bars within experiment and treatment labeled with different letters are significantly different (Student's paired $t$ test, $P=0.05$ ).

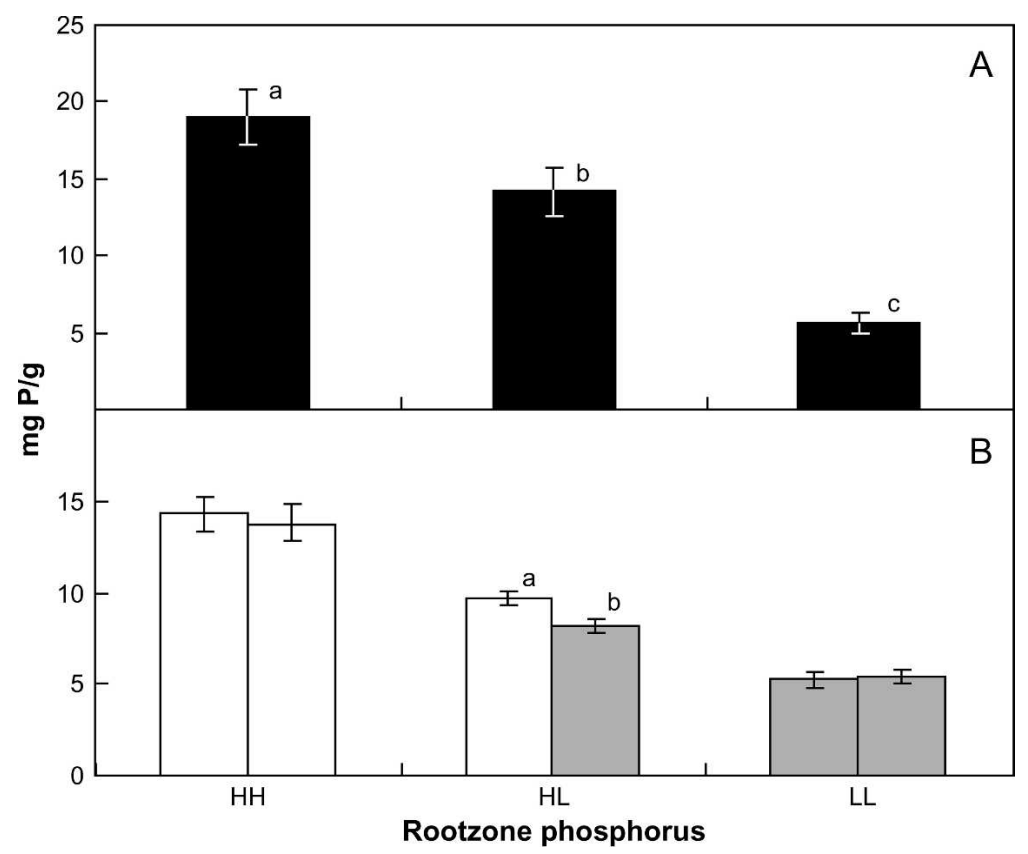

Fig. 4. Phosphorus concentration of different shoots (A) and roots (B) in the horizontal split root experiment. HH received phosphorus on both sides of the root zones. HL received phosphorus on only one side of the root zone. LL received no phosphorus on either side of the root zone. Shaded bars represent root mass from the no phosphorus portion of the root zone and white bars represent root mass from the side with phosphorus added. Error bars represent SE; bars within experiment and treatment labeled with different letters are significantly different (Student's paired $t$ test, $P=0.05$ ). 
crops such as wheat (Triticum aestivum L.) and beans (Phaseolus L.), which have been selected annually over thousands of years.

The tissue $\mathrm{P}$ concentration of turfgrass species varies widely. Waddington and Zimmerman (1972) reported that creeping bentgrass had an average tissue $P$ concentration of $7.6 \mathrm{mg} \cdot \mathrm{g}^{-1}$. In a later study, creeping bentgrass was found to have tissue $P$ levels of $5 \mathrm{mg} \cdot \mathrm{g}^{-1}$ and no change in growth occurred when tissue P levels were found as high as $8.4 \mathrm{mg} \cdot \mathrm{g}^{-1}$ (Waddington et al., 1978). Jones (1980) concluded that the sufficiency range for most turfgrass species is 3.0 to $5.5 \mathrm{mg} \cdot \mathrm{g}^{-1}$. In the present study, shoot $\mathrm{P}$ levels were high compared with commonly reported sufficiency levels, although deficiency symptoms (purple stolons and leaves) were observed in the LL-treated plants that had tissue $\mathrm{P}$ concentrations of $\approx 5 \mathrm{mg} \cdot \mathrm{g}^{-1}$. Tissue $\mathrm{P}$ concentration paralleled growth responses to the treatments (Fig. 4). The shoots from the "no P" treatment had $30 \%$ of the P concentration of the treatments containing $\mathrm{P}$. The $\mathrm{P}$ treated plants had equivalent $P$ concentration in the shoots regardless of the presence of spatial heterogeneity. The $\mathrm{P}$ concentration of roots in the high $\mathrm{P}$ side of the HL treatment was $17 \%$ greater than roots in the "no P" side. Moreover, the $\mathrm{P}$ concentration of roots in the "no P" side of the HL treatment was greater than the $\mathrm{P}$ concentration of roots in the treatment $(\mathrm{LL})$ receiving no $\mathrm{P}$ in either side of the root zone.

Vertical localization of phosphorus. In the vertical localization of $\mathrm{P}$, experiment differences in shoot characteristics caused by $\mathrm{P}$ treatments did not begin to appear until after Week 6 of the experiment when the plants receiving the complete nutrient solution began to have greater shoot mass than plants in both Al-P-amended treatments $(P<$ $0.0006)$. This delay in response may have been because the plants were transplanted from an environment adequate in P. Shoot growth of the control treatment was three- to five-fold greater than that of the two treatments using Al-P as the sole source of P (Fig. $5)$. This same pattern was observed in the tiller densities measured throughout the first 7 weeks of the experiment (data not shown). Reduced shoot growth may be the result of a significant reduction in the $\mathrm{P}$ concentration of the shoots in the Al-P-treated plants throughout the experiment (Fig. 6). Shoot tissue P concentration of the control treatment was significantly higher in Weeks 3 to 6 than Weeks 1 and 2 and then declined during the latter weeks (Weeks 8 and 9) of the experiment as the plants grew larger than those in the Al-P treatments. The Al-P-treated plants maintained consistent shoot $\mathrm{P}$ concentration throughout the experiment (Fig. 6) and never showed typical $\mathrm{P}$ deficiency symptoms, a purplish leaf color that is darkest at the crown (Turner and Hummel, 1992), which was observed in the low $\mathrm{P}$ treatments of the horizontal split root experiment. The tissue $\mathrm{P}$ levels (peaking at $11.1 \mathrm{mg} \cdot \mathrm{g}^{-1}$ in Week 3 and declining to $2.9 \mathrm{mg} \cdot \mathrm{g}^{-1}$ in Week 9) of control treatment plants in the vertical $\mathrm{P}$

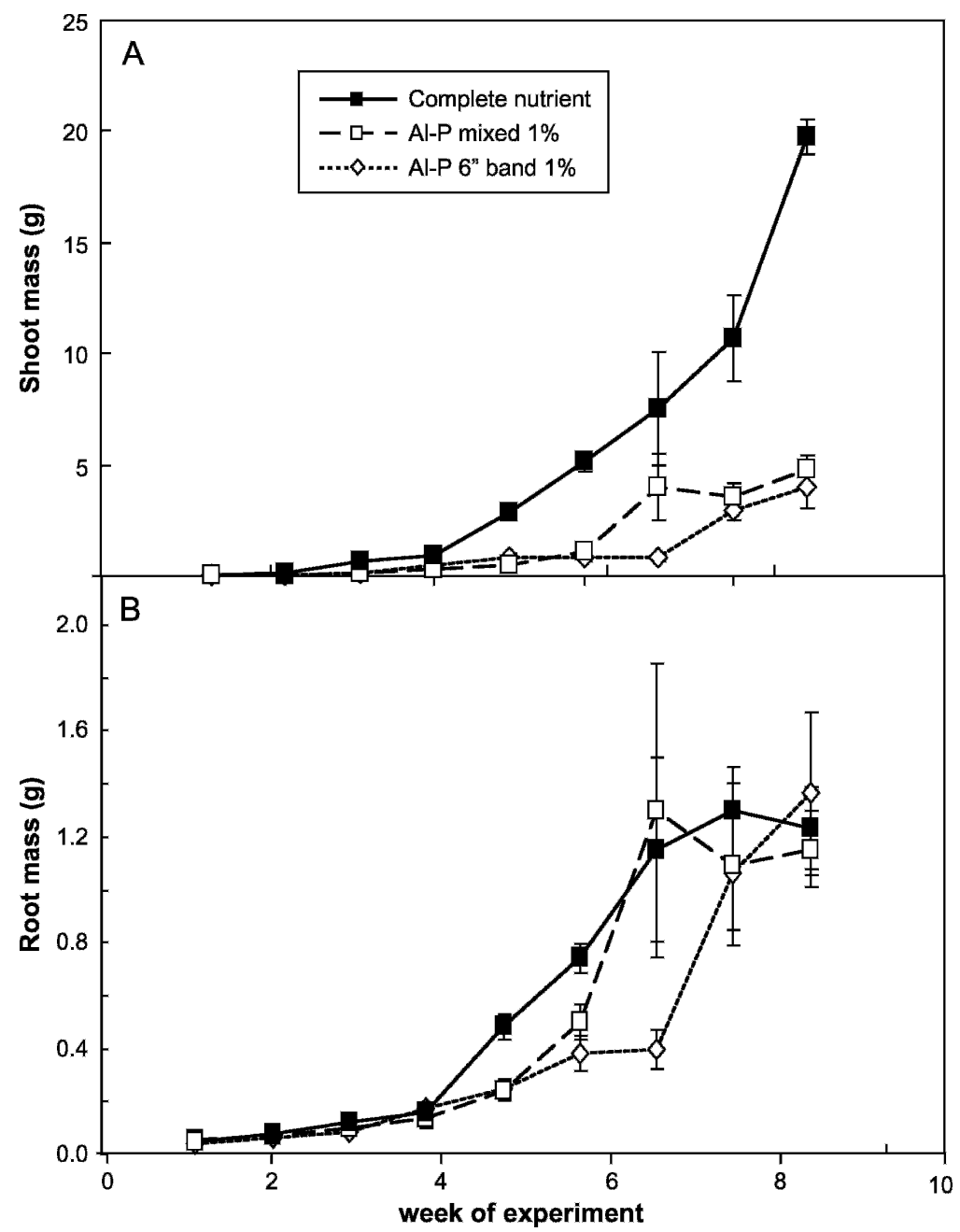

Fig. 5. Shoot (A) and root mass (B) of creeping bentgrass during a 9-week growth experiment in response to a complete nutrient solution and phosphorus-free nutrient solutions with alumina-bound phosphorus fertilizer mixed throughout the root zone and banded in the lower $10 \mathrm{~cm}$ of a $30-\mathrm{cm}$ root zone. Error bars represent SE.

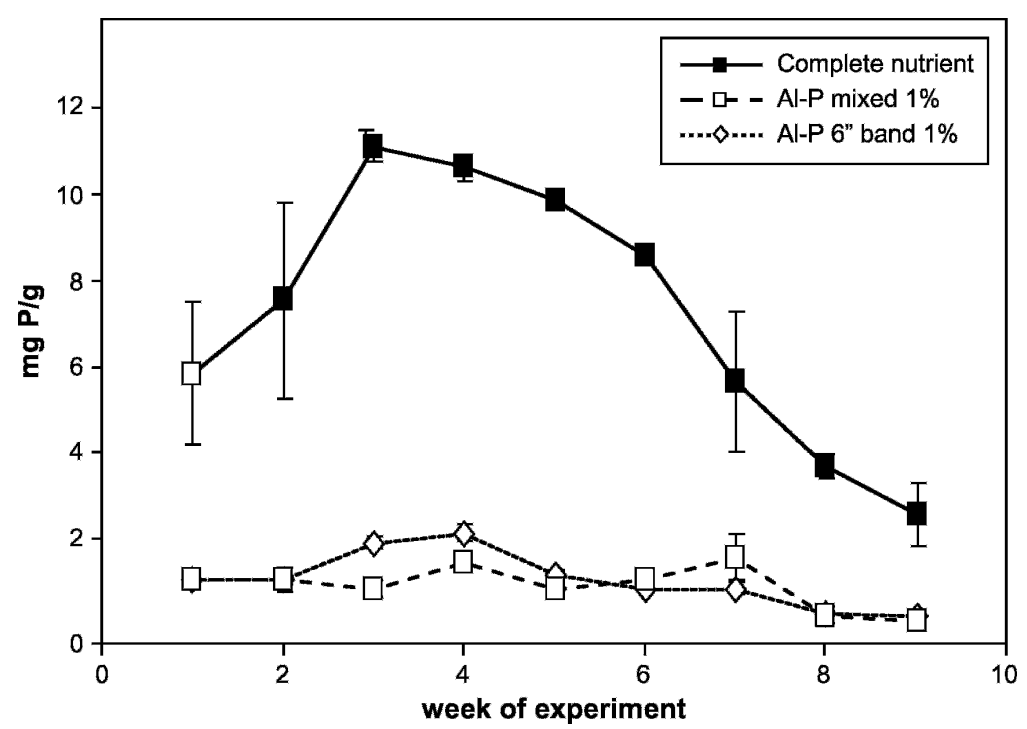

Fig. 6. Phosphorus concentration of creeping bentgrass shoots during a 9-week growth experiment in response to a complete nutrient solution and phosphorus-free nutrient solutions with alumina-bound phosphorus fertilizer mixed throughout the root zone and banded in the lower $10 \mathrm{~cm}$ of a $30-\mathrm{cm}$ root zone. Error bars represent SE. 
localization experiment could be considered very high based on the numbers reported in the literature and may be evidence supporting the concept that most turfgrass species are "luxury consumers" of nutrients when nutrients are available in large amounts (Hull, 1992). The Al-P-treated plants may have become P-deficient with tissue $\mathrm{P}$ levels falling below $1.8 \mathrm{mg} \cdot \mathrm{g}^{-1}$ in Weeks 8 and 9 of the experiment.

Despite the differences in shoot growth, root growth for the 9 weeks of the experiment appeared to be identical among treatments with the exception of Week 5 when the root growth in both Al-P-amended pots was lower than the control $(P=0.0361)$ and in Week 7 when the plants in the $1 \%$ Al-P-banded pot had less than half of the root mass of the control treatment and the 1\% Al-P mixed treatment $(P=0.0120)$. The root-to-shoot ratios of the Al-P-treated plants were significantly greater $(\approx 100 \%)$ than those of plants in the control treatment (Fig. 7). This increase in root-to-shoot ratios is likely because the plants grown in the Al-P-amended media produced lower shoot mass while maintaining similar root growth as plants in the control treatment (Fig. 5). The Al-P treatment increased root-to-shoot ratios over the control treatment appears to be a response by the plants to obtain greater amounts of $\mathrm{P}$ by exploiting more of the Al-P throughout the root zone or in the bottom $10 \mathrm{~cm}$ of the root zone. In most natural soils, nutrient bioavailability, particularly that of $\mathrm{P}$, is greatest at the surface of the soil (Chu and Chang, 1966; Pothuluri et al., 1986; Pregitzer et al., 1993). Bean plants with shallower basal root angles are more competitive for surface $\mathrm{P}$ (Lynch and Brown, 2001; Rubio et al., 2003) presumably because of increased root length density near the soil surface where $\mathrm{P}$ is present.

The increase in root-to-shoot ratio observed in the Al-P-treated pots that ranged from 0.22 to 0.45 from Week 3 on compared with the control pots that ranged from 0.06 to 0.15 (Fig. 7) could be the result of the reduced overall size of the plants in the Al-P-treated pots. Within a cultivar (Larcher, 1995) and across broad taxonomic ranges (Enquist and Niklas, 2002), smaller, less mature plants have a tendency to have higher root-to-shoot ratios (Wilson, 1988). The plant in the Al-Ptreated pots exhibited reduced shoot growth, but the similarities in the root mass among all treatments in Weeks 8 and 9 (Fig. 4) show that the carbon allocation between roots and shoots in the Al-P-treated plants was being shifted from shoots to roots in contrast to being a function of reduced plant growth as was observed in the horizontal split root experiment (Figs. 2 and 3 ).

For the last 2 weeks of the experiment, root growth in the top $15 \mathrm{~cm}$ and bottom 15 $\mathrm{cm}$ of the growth tubes was measured. Plants in both Al-P treatments had the same root mass in the top half of the root zone. The control plants had significantly $(P<0.05)$ less root mass below $15 \mathrm{~cm}$ of depth $(0.15 \mathrm{~g})$ compared with the plants in the Al-P treatments $(0.35 \mathrm{~g}$ and $0.43 \mathrm{~g})$ in Week 8 despite having equal or greater total root mass than both of the Al-P-treated plants. The root zones with the Al-P banded in the lower portion of the root zone had greater root mass in the lower half of the root zone $(0.56 \mathrm{~g})$ than both the control $(0.22)$ and the Al-P mixed $(0.35 \mathrm{~g})$ treatments in Week 9 (Fig. 8). The control plants were given $\mathrm{P}$ in a nutrient solution applied to the surface of the pots, which mimics typical turfgrass growth environments. The addition of the Al-P to soil in the bottom half of the pot inverted the $\mathrm{P}$ availability regime that is typically found in soils. It was shown that mixing Al-P throughout the root zone could increase root mass below $15 \mathrm{~cm}$ of depth but that banding the Al-P deeper in the root zone would result in an even greater root mass below the $15-\mathrm{cm}$

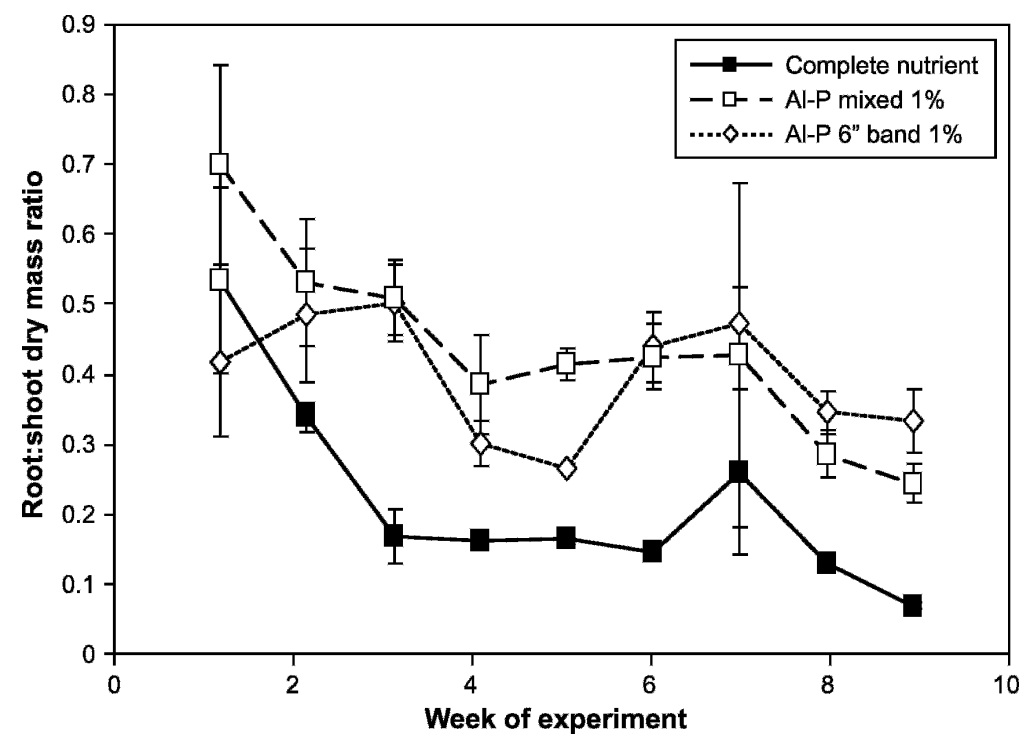

Fig. 7. Root-to-shoot ratio of creeping bentgrass during a 9-week growth experiment in response to a complete nutrient solution and phosphorus-free nutrient solutions with alumina-bound phosphorus fertilizer mixed throughout the root zone and banded in the lower $10 \mathrm{~cm}$ of a $30-\mathrm{cm}$ root zone. Error bars represent SE.

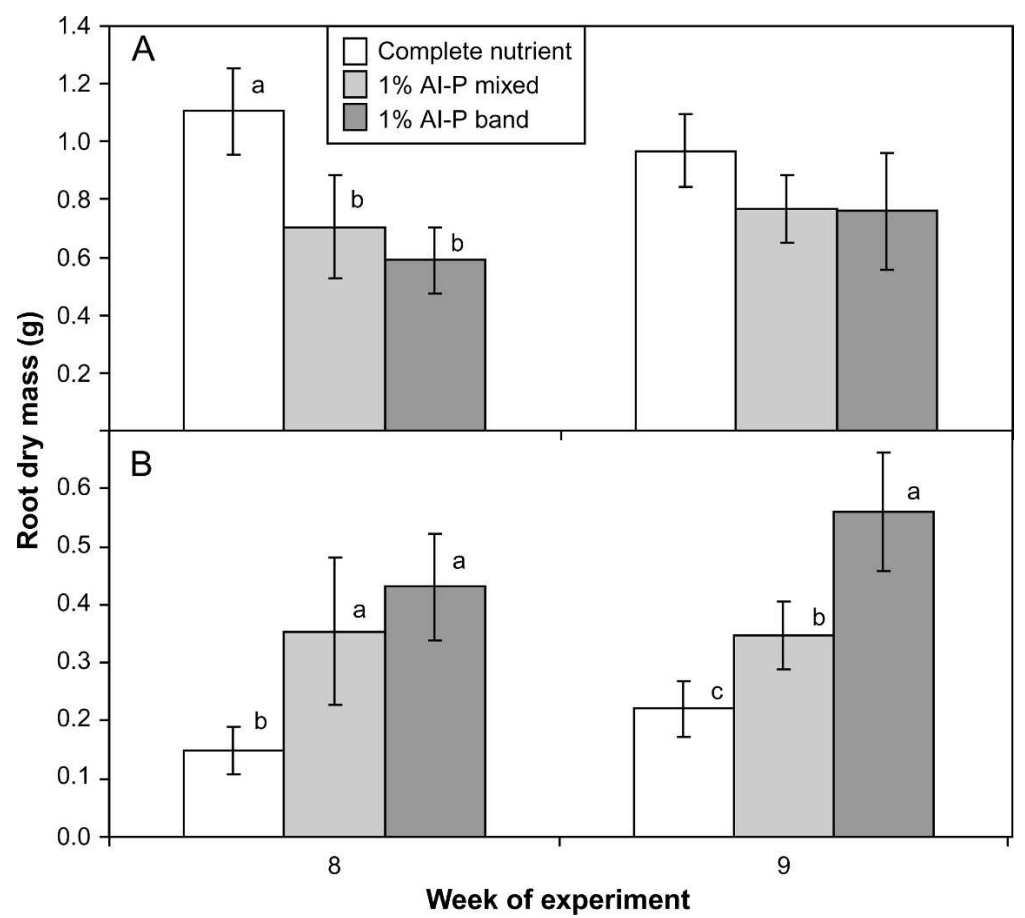

Fig. 8. Root mass in the top $15 \mathrm{~cm}(\mathbf{A})$ and bottom $15 \mathrm{~cm}(\mathbf{B})$ of the root zone of creeping bentgrass in Weeks 8 and 9 in response to a complete nutrient solution and phosphorus-free nutrient solutions with alumina-bound phosphorus fertilizer mixed throughout the root zone and banded in the lower $10 \mathrm{~cm}$ of a $30-\mathrm{cm}$ root zone. Error bars represent SE; bars within root depth and week of experiment labeled with different letters are significantly different (Fisher's protected least significant difference, $P=0.05$ ). 
depth compared with that observed in the other treatments. Deep root systems are important for healthy turf in that they allow the plant to obtain water from deeper in the soil profile (Huang and Gao, 2000). This allows leaf stomates to remain open supporting continued transpirational cooling and carbon fixation during times of periodic heat stress and drought. Future research may explore the effects of Al-P as the sole source of P on the ability of creeping bentgrass to survive temporary drought conditions experienced during the late afternoon on golf greens.

Other than encouraging deeper root growth, another potential benefit of providing $\mathrm{P}$ deeper in the root zone using Al-P is the inhibition of annual bluegrass invasion into creeping bentgrass. Increasing $P$ availability has been shown to encourage annual bluegrass invasion on golf greens (Waddington et al., 1978) and to favor annual bluegrass growth in mixed stands with creeping bentgrass turf (Kuo, 1993). If $P$ were only available below $20 \mathrm{~cm}$ of depth, annual bluegrass would not be able to obtain P necessary for growth because annual bluegrass found on golf greens has very little root mass below $12 \mathrm{~cm}$ of depth (Lyons, unpublished data). It is also possible that placing $\mathrm{P}$ deeper in the root zone may select for more deeply rooted ecotypes of annual bluegrass. Although this may increase the ability of annual bluegrass to invade creeping bentgrass, it may also eliminate some of the undesirable plant characteristics related to the shallow root system typically found with annual bluegrass.

Sand-based root zones used in golf course greens construction are ideal for resisting problems associated with compaction but lack the ability to provide proper nutrition, and increased nutrients are needed when the greens are young to promote proper growth and turfgrass quality (McCellan et al., 2007). Generally, it is believed that P loss occurs primarily through runoff. Although runoff from turfgrass can occur, turfgrass systems are generally considered good at minimizing $P$ surface runoff unless a dramatic rainfall event occurs (Kaufman and Watschke, 2007; Linde and Watschke, 1997; Shuman, 2002). Although it is widely believed P leaching from sand-based golf greens is rare (McCellan et al., 2007; Sartain and Brown, 1998), it has been shown that in sandy soils, $P$ leaching can be substantial, especially during establishment (Shuman, 2001). The use of Al-P has been shown to significantly reduce $P$ leaching in sandy soils (Borch et al., 1998, 2003) and although leaching was not measured in this experiment, the ability of buffered $\mathrm{P}$ to reduce $P$ escape is significant. In addition, the increased amount of deeper roots will allow the plant to possibly capture more nitrogen potentially reducing nitrate leaching (Bowman et al., 1998).

\section{Conclusions}

Our results show that creeping bentgrass roots proliferate in soil domains with greater $\mathrm{P}$ bioavailability, and the use of a buffered $\mathrm{P}$ source to localize P supply deeper in the soil profile results in deeper bentgrass rooting. The buffered $\mathrm{P}$ source reduced shoot growth but not root growth. The production of bentgrass stands with deeper roots and reduced shoot growth would be advantageous in many turfgrass systems by reducing the need for mowing while increasing drought tolerance and decreasing the fitness of shallow-rooted weeds such as moss (Bryum argenteum Hedw.) and annual bluegrass. Although not measured directly in this study, the use of buffered $\mathrm{P}$ sources substantially reduces $\mathrm{P}$ leaching from inert media such as sand (Borch et al., 1998, 2003). The use of buffered $P$ sources appears to offer several advantages over conventional turfgrass fertilization.

The response of creeping bentgrass to spatial $\mathrm{P}$ supply creates an opportunity to increase root-to-shoot ratios and increase overall rooting depth. The effects of altered root architecture on stress tolerance still needs to be explored. In addition to providing adequate but not excessive $\mathrm{P}$, buffered $\mathrm{P}$ has the potential to minimize nutrient pollution by reducing the $\mathrm{P}$ that can move through sand-based root zones. The feasibility of using Al-P in turfgrass applications should be explored under field conditions to determine its efficacy.

\section{Literature Cited}

Anonymous 1954. New grasses from Pennsylvania. USGA J. and Turf Mgt. August.

Borch, K., K.M. Brown, and J.P. Lynch. 1998. Improvement of bedding plant quality and stress resistance with low phosphorus. HortTechnology 8:20-24.

Borch, K., C. Miller, K.M. Brown, and J.P. Lynch. 2003. Improved drought tolerance in marigold by manipulation of root growth with bufferedphosphorus nutrition. HortScience 38:212-216.

Bowman, D.C., D.A. Devitt, M.C. Engelke, and T.W.J. Rufty. 1998. Root architecture affects nitrate leaching from bentgrass turf. Crop Sci. 38:1633-1639.

Brown, K.M., C.R. Miller, L. Kuhns, D.J. Beattie, and J.P. Lynch. 1999. Improvement of Rhododendron and Forsythia growth with bufferedphosphorus fertilizer. J. Environ. Hort. 17:153157.

Chu, W.K. and K.C. Chang. 1966. Surface activity of inorganic soil phosphorus. Soil Sci. 101: 459-464.

Coltman, R.R., G.C. Gerloff, and W.H. Gabelman. 1982. A sand culture system for simulating plant responses to phosphorus in soil. J. Amer. Soc. Hort. Sci. 107:938-942.

Comerford, N. 1998. Soil phosphorus bioavailability, p. 136-147. In: Lynch, J. and J. Deikman (eds.). Phosphorus in plant biology: Regulatory roles in molecular cellular, organismic, and ecosystem processes. Amer. Soc. of Plant Physiol., Rockville, MD.

DaCosta, M. and B.R. Huang. 2006. Osmotic adjustment associated with variation in bentgrass tolerance to drought stress. J. Amer. Soc. Hort. Sci. 131:338-344.

Elliott, G.C. 1989. Evaluation of sand-alumina-P media for studies of P nutrition. J. Plant Nutr. 12:265-278.
Enquist, B.J. and K.J. Niklas. 2002. Global allocation rules for patterns of biomass partitioning in seed plants. Science 295:1517-1520.

Green Section Staff. 1993. USGA recommendations for a method of putting green construction. USGA Green Section Record 31:1-3.

Havis, J.R. and J.H. Baker. 1985. Phosphorus availability in peat-sand media fertilized with several phosphorus sources. J. Environ. Hort. 3:153-155.

Hodge, A. 2004. The plastic plant: Root responses to heterogeneous supplies of nutrients. New Phytol. 162:9-24.

Holt, C.C. and R.L. Davis. 1948. Differential responses of Arlington and Norbeck bentgrasses to kinds and rate of fertilizer. Agron. J. 40:282-284.

Huang, B. and D.M. Eissenstat. 2000. Root plasticity in exploiting water and nutrient heterogeneity, p. 111-132. In: Wilkinson, R.E. (ed.) Plant-environment interactions. Marcel Dekker, New York, NY.

Huang, B. and H. Gao. 2000. Growth and carbohydrate metabolism of creeping bentgrass cultivars in response to increasing temperatures. Crop Sci. 40:1115-1120.

Huff, D. and P. Landschoot. 1999. Comparing the new bentgrasses. Grounds Maintenance. 35: $15-22$.

Hull, R.J. 1992. Energy relations and carbohydrate partitioning in turfgrasses, p. 175-206. In: Waddington, D.V., R.N. Carrow, and R.C. Shearman (eds.). Turfgrass agronomy monograph. Vol. 32. ASA CSSA, SSSA, Madison, WI.

Jones, J.R., Jr. 1980. Turf analysis. Golf Course Mgt. 48:29-32.

Kaufman, G.L., III and T.L. Watschke. 2007. Phosphorus and sediment runoff after core cultivation of creeping bentgrass and perennial ryegrass turfs. Agron. J. 99:141-147.

Klecka, A. 1937. Vliv Seslapavani na asociaci travnatych porustu. Sborn. Csl. Akad. Zemed. 12:715-724. Cited in Beard, J.B. 1973. Turfgrass: Science and culture. Prentice Hall, Englewood Cliffs, NJ.

Kuo, S. 1993. Calcium and phosphorus influence creeping bentgrass and annual bluegrass growth in acidic soils. HortScience 28:713716.

Larcher, W. 1995. Physiological plant ecology. 3rd Ed. Springer, New York, NY.

Lin, Y.P., E.J. Holcomb, and J.P. Lynch. 1996. Marigold growth and $\mathrm{P}$ leaching from media amended with P-charged alumina. HortScience 31:94-98

Linde, D.T. and T.L. Watschke. 1997. Nutrients and sediment in runoff from creeping bentgrass and perennial ryegrass turfs. J. Environ. Qual. 87:176-182.

Lynch, J.P. and S.E. Beebe. 1995. Adaptation of beans (Phaseolus vulgaris L.) to low phosphorus availability. HortScience 30:11651171.

Lynch, J.P. and K.M. Brown. 2001. Topsoil foraging - An architectural adaptation of plants to low phosphorus availability. Plant Soil 237:225-237.

Lynch, J.P., E. Epstein, A. Lauchli, and G. Weigt. 1990. An automated greenhouse and sand culture system suitable for the studies of $\mathrm{P}$ nutrition. Plant Cell Environ. 13:547-554.

Lyons, E.M., D. Huff, and J. Lynch. 2000. Use of alumina bound phosphorus (Al-P) to reduce phosphorus leaching and alter turfgrass growth, p. 139. In: Agronomy Abstracts. ASA, CSSA and SSSA, Madison, WI.

McCellan, T.A., R.C. Shearman, R.E. Gaussoin, M. Mamo, C.S. Wortman, G.L. Horst, and D.B. 
Marx. 2007. Nutrient and chemical characterization of aging golf course putting greens: Establishment and rootzone mixture treatment effects. Crop Sci. 47:193-199.

Murphy, J. and J.P. Riley. 1962. A modified single solutions method for the determination of phosphate in natural waters. Anal. Chim. Acta 27:31-36.

Pellet, H.M. and E.C. Roberts. 1963. Effects of mineral nutrition on high temperature induced growth retardation of Kentucky bluegrass. Agron. J. 55:473-476.

Pothuluri, C.J., J.R. Okalebo, L.P. Simmonds, and K.W. Gathua. 1986. Phosphorus uptake from soil layers having different soil test phosphorus levels. Agron. J. 78:991994.

Pregitzer, K.S., R.L. Hendrick, and R. Fogel. 1993. The demography of fine roots in response to patches of water and nitrogen. New Phytol. 125:575-580.
Robinson, D. 1994. The responses of plants to nonuniform supplies of nutrients. New Phytol. 127:635-674.

Robinson, D. 2001. Root proliferation, nitrate inflow and their carbon costs during nitrogen capture by competing plants in patchy soil. Plant Soil 232:41-50.

Rubio, G., H. Liao, X. Yan, and J. Lynch. 2003. Topsoil foraging and its role in plant competitiveness for phosphorus in common bean. Crop Sci. 43:598-607.

Sartain, J.B. and E.A. Brown. 1998. Enhancemen of phosphorus retention in USGA greens, $\mathrm{p}$. 129. In: 1998 Agronomy abstracts. ASA, CSSA, and SSSA, Madison, WI.

Shuman, L.M. 2001. Phosphate and nitrate movement through simulated golf greens. Water Air Soil Pollut. 129:305-318.

Shuman, L.M. 2002. Phosphorus and nitrate nitrogen in runoff following fertilizer application to turfgrass. J. Environ. Qual. 31:1710-1715.
Tanaka, M., R. Snyder, J.K. Boateng, W.J. Lamont, M.D. Orzolek, K.M. Brown, and J.P. Lynch. 2006. Utility of alumina buffered phosphorus fertilizer for vegetable production. HortScience 41:775-779.

Turner, T.R. and N.W. Hummel, Jr. 1992. Nutritional requirements and fertilization. In: Waddington, D.V., R.N. Carrow, and R.C. Shearman (eds.). Turfgrass. Agronomy Monogr. 32:385-440. ASA, CSSA, SSSA, Madison, WI.

Waddington, D.V., T.R. Turner, J.M. Duich, and E.L. Moberg. 1978. Effect of fertilization on 'Penncross' creeping bentgrass. Agron. J. 70:713-718.

Waddington, D.V. and T.L. Zimmerman. 1972 Growth and chemical composition of eight grasses grown under high water table conditions. Commun. Soil Sci. Plant Anal. 3:329-337.

Wilson, J.B. 1988. A review of evidence on the control of shoot: Root ratio, in relation to models. Ann. Bot. (Lond.) 61:433-449. 